\title{
Sistem Manajemen Kartu Nama dengan OCR dan Ekstraksi Informasi Otomatis
}

\author{
Robby Darmawan, Departemen Informatika, Institut Sains dan Teknologi Terpadu Surabaya, \\ Aris Nasuha, Departmen Pendidikan Elektro, Universitas Negeri Yogyakarta, Yogyakarta, Indonesia, \\ Lukman Zaman, Departemen Informatika, Institut Sains dan Teknologi Terpadu Surabaya, \\ Hendrawan Armanto, Departemen Informatika, Institut Sains dan Teknologi Terpadu Surabaya
}

\begin{abstract}
Abstrak - Sebagai pelaku bisnis, kartu nama adalah salah satu hal yang penting untuk bertukar informasi. Namun kartu nama biasanya mudah hilang atau rusak, sehingga beberapa orang biasanya menyimpan informasi dari kartu nama itu pada telepon genggam atau komputer mereka. Penelitian ini akan membuat sistem manajemen kartu nama baik individu dan juga perusahaan dengan ekstraksi informasi kartu nama otomatis untuk mempermudah pengguna perorangan ataupun perusahaan dalam melakukan penyimpanan kartu nama para kolega. Untuk mewujudkan aplikasi yang dilengkapi dengan fitur tersebut dilakukan proses pengenalan karakter pada gambar kartu nama menggunakan Tesseract OCR dan information extraction memanfaatkan klasifikasi entity dengan membangun classifier menggunakan Naive Bayes dan mengkombinasikannya dengan rule based. Hasil uji coba yang telah dilakukan mendapatkan performa $85.1 \%$ untuk pengenalan karakter dan $86 \%$ untuk pengklasifikasian entity. Dilakukan juga uji coba fungsionalitas terhadap setiap fitur pada sistem ini dengan menggunakan metode blackbox testing yang memastikan setiap aksi yang dilakukan pengguna akan menghasilkan output sesuai target yang diharapkan. Selain itu, dari hasil kuisioner yang berisikan tentang usability dari sistem ini, sebagian besar responden merasa terbantu dalam memanajemen kartu nama dengan menggunakan sistem aplikasi ini.
\end{abstract}

Kata Kunci-Kartu Nama, Ekstraksi Informasi, Tesseract OCR, Klasifikasi Entity.

\section{PENDAhUluan}

$\mathrm{D}$ i zaman ini, dengan pesatnya usaha di segala bidang, membuat para pelaku bisnis harus mampu bersaing dengan baik untuk memasarkan produk-produk mereka. Salah satu hal yang wajib dimiliki oleh seorang pelaku bisnis untuk sukses adalah pandai menjalin relasi dengan orang lain [1].

Robby Darmawan, Departemen Informatika, FST, Institut Sains dan Teknologi Terapan Surabaya, Surabaya, Jawa Timur, Indonesia (e-mail: robby2@mhs.stts.edu)

Aris Nasuha, Departmen Pendidikan Elektro Universitas Negeri Yogyakarta, Jawa Tengah, Indonesia (e-mail: arisnasuha@uny.ac.id)

Lukman Zaman, Departemen Informatika, FST, Institut Sains dan Teknologi Terapan Surabaya, Surabaya, Jawa Timur, Indonesia (e-mail: lz@stts.edu)

Hendrawan Armanto, Departemen Informatika, FST, Institut Sains dan Teknologi Terapan Surabaya, Surabaya, Jawa Timur, Indonesia (e-mail: hendrawan@stts.edu)
Hal tersebut memaksa pelaku bisnis untuk bertemu dan berkenalan dengan banyak orang-orang baru baik sebagai rekan kerja, pelanggan, ataupun lainnya. Tentu bukanlah hal yang mudah bagi sebagian besar orang untuk bisa mengingat data kontak dan alamat seluruh orang yang mereka kenal, sehingga banyak orang menjadikan kartu nama sebagai solusi untuk hal tersebut.

Penggunaan kartu nama memiliki tujuan yang berbeda dilihat dari siapa yang memberikan maupun yang menerima kartu bisnis tersebut. Misalnya saja, untuk para pemasar, kartu nama bisnis tidak hanya digunakan untuk memberikan informasi mengenai detail informasi kontak saja tetapi juga sebagai representasi dari perusahaan Anda [2]. Biasanya sebuah perusahaan akan memiliki banyak kartu nama, baik itu pelanggan atau rekan bisnis perusahaan tersebut. Jika tidak dikelola dengan baik, biasanya data tersebut akan mudah hilang.

Semakin banyak orang tersebut berkenalan dengan orang baru, semakin banyak pula kartu nama yang akan ia miliki, di mana tentunya tidak mudah untuk melakukan penyimpanan kartu nama tersebut. Kartu nama biasanya mudah hilang dan rusak, sehingga beberapa orang biasanya menyimpan informasi dari kartu nama itu pada telepon genggam atau komputer mereka.

Mengetik informasi dari kartu nama biasanya akan membutuhkan waktu yang relatif lama terutama jika informasi yang akan dimasukkan cukup banyak. Sedangkan jika hanya difoto, informasi dari kartu nama tersebut harus diketik ulang setiap kali akan digunakan.

Berdasarkan masalah tersebut, sistem manajemen kartu nama ini akan digunakan untuk mengatasi permasalahanpermasalahan di atas. Sistem manajemen kartu nama ini akan digunakan melalui proses pengenalan informasi pada kartu nama, penyimpanan, hingga penggunaan dari kartu nama yang telah disimpan baik pada pengguna individu maupun perusahaan.

Kontribusi utama dari artikel ini adalah:

1. Membuat sistem manajemen kartu nama yang dapat mengelola data kartu nama dengan baik.

2. Membuat fitur ekstraksi informasi otomatis dari gambar kartu nama.

3. Membuat sistem manajemen kartu nama sebuah perusahaan yang dapat mengelola kartu nama dari karyawan perusahaan tersebut. 


\section{TINJAUAN PUSTAKA}

Untuk mendukung sistem yang dibuat mengenai sistem manajemen kartu nama dengan ekstraksi informasi kartu nama otomatis dibutuhkan beberapa komponen pendukung seperti Android Studio, Laravel, Lumen, MySQL, Midtrans, OneSignal, Flask, Tesseract, NumPy, OpenCV, Scikit Learn.

\section{A. Android Studio}

Android Studio adalah Integrated Development Environment (IDE) resmi dari Android untuk pengembangan aplikasi Android [3]. IDE ini merupakan pengganti dari Eclipse Android Development Tools yang sebelumnya merupakan IDE utama untuk pengembangan aplikasi Android. Android studio pertama kali diumumkan pada tanggal 16 Mei 2013 di Google I/O conference.

\section{B. Laravel}

Laravel adalah sebuah framework yang digunakan untuk web development di PHP [4]. Laravel dibangun dengan menggunakan konsep MVC (model view controller). MVC adalah pembangunan aplikasi dengan konsep pemisahan komponen-komponen aplikasi, seperti manipulasi data, controller, dan juga user interface. Laravel dirancang untuk meningkatkan kualitas perangkat lunak dengan mengurangi biaya pengembangan awal dan biaya pemeliharaan, dan untuk meningkatkan pengalaman bekerja dengan aplikasi yang menyediakan sintaks yang ekspresif, jelas, dan menghemat waktu.

\section{Lumen}

Lumen merupakan salah satu micro-framework yang dikembangkan oleh Taylor Otwell, pengembang yang berada di balik framework PHP paling populer saat ini, Laravel. Lumen adalah micro framework PHP turunan dari Laravel Framework yang berorientasi pada ukuran yang kecil dan kecepatan pemrosesan halaman yang tinggi. Disebut sebagai micro framework karena ditujukan sebagai pendukung infrastruktur layanan Micro Services di server yang saat ini sedang populer digunakan. Lumen diklaim memiliki kecepatan 1900 request per detik [5], atau 100 request per detik lebih cepat dari Slim Framework versi 3 dan Silex.

\section{D. $M y S Q L$}

MySQL adalah sebuah implementasi dari sistem manajemen basis data relasional (RDBMS) yang didistribusikan secara gratis di bawah lisensi GPL (General Public License). Setiap pengguna dapat secara bebas menggunakan MySQL, namun dengan batasan perangkat lunak tersebut tidak boleh dijadikan produk turunan yang bersifat komersial. MySQL sebenarnya merupakan turunan salah satu konsep utama dalam basisdata yang telah ada sebelumnya; SQL (Structured Query Language). SQL adalah sebuah konsep pengoperasian basis data, terutama untuk pemilihan atau seleksi dan pemasukan data, yang memungkinkan pengoperasian data dikerjakan dengan mudah secara otomatis.

\section{E. Midtrans}

Midtrans merupakan payment gateway yang menyediakan layanan pemrosesan pembayaran online secara komprehensif. Midtrans menyediakan berbagai macam cara untuk transaksi pembayaran seperti menggunakan Virtual Account, GoPay, Credit Card dan Bank Transfer. Midtrans
Payments menjamin proses integrasi yang mudah dan cepat di berbagai platform. Beberapa platform yang mendukung adalah iOS, Android, dan PHP.

\section{F. OneSignal}

One Signal adalah service push notification untuk website dan aplikasi mobile. OneSignal mensupport sebagian besar native dan mobile platform dengan menyediakan SDK untuk masing-masing platform, RESTful server API, dan online dashboard untuk melihat performa, statistik penggunaan maupun operasi push notification.

\section{G. Flask}

Flask adalah sebuah web framework yang ditulis dengan bahasa Python dan tergolong sebagai jenis microframework. Flask termasuk pada jenis microframework karena tidak memerlukan suatu alat atau pustaka tertentu dalam penggunaannya. Selain itu, meskipun Flask disebut sebagai microframework, bukan berarti Flask mempunyai kekurangan dalam hal fungsionalitas. Microframework disini berarti bahwa Flask bermaksud untuk membuat core dari aplikasi ini sesederhana mungkin tapi tetap dapat dengan mudah ditambahkan [6].

\section{H. Tesseract}

Tesseract adalah mesin pengenal karakter optik yang bersifat gratis. Tesseract OCR adalah proyek open-source, dimulai oleh Hewlett-Packard, kemudian Google mengambil alih pengembangan [7]. Kini, tesseract telah dianggap sebagai salah satu mesin perangkat lunak OCR bebas yang paling akurat yang tersedia.

\section{NumPy}

NumPy merupakan sebuah library paket dasar Python guna keperluan komputasi scientific. Selain digunakan untuk masalah-masalah scientific dan operasi aritmatika, NumPy juga dapat digunakan sebagai sebuah penampung data, seperti contoh untuk menampung dataset gambar yang digunakan pada Penelitian ini. Objek utama pada NumPy berupa sebuah array multidimensi. Objek multidimensional array ini biasa disebut sebagai sebuah ndarray ( $\mathrm{N}$ dimensional array).

\section{J. OpenCV}

OpenCV (Open source computer vision) adalah library pemrograman yang terutama ditujukan untuk bidang computer vision. Library ini digunakan dengan tujuan untuk membantu proses pengolahan citra. Library ini akan digunakan untuk membaca gambar dan video. Selain itu, library ini juga membantu proses-proses pada data gambar, seperti resize, rotate, dan convert color. Library ini juga membantu dalam melakukan pendeteksian mata, pendeteksian wajah, juga dalam memotong atau mengambil area tertentu pada gambar.

\section{K. Scikit Learn}

Scikit-learn atau sklearn adalah modul untuk bahasa pemograman python yang dibangun diatas NumPy, SciPy, dan matplotlib, fungsinya dapat membantu melakukan processing data ataupun melakukan training data untuk kebutuhan machine-learning [8]. Ada banyak fitur yang dapat digunakan dengan sklearn ini, seperti Classification, Regression, Clustering, Dimensionality reduction, Model selection, dan Preprocessing data. 


\section{ANALISA SISTEM}

Pada bagian ini akan dijelaskan tentang analisa sistem dari Sistem Manajemen Kartu Nama dengan Ekstraksi Informasi Kartu Nama Otomatis. Sebelum program dibuat, terdapat berbagai macam hal yang perlu disiapkan atau dilakukan terlebih dahulu. Salah satu hal yang perlu dilakukan adalah melakukan analisa terhadap permasalahan yang ditemukan. Setelah menemukan masalah dan melakukan analisa, dibuatlah kesimpulan dari hasil analisa dimana adanya kebutuhan untuk membuat sebuah program dalam menyelesaikan masalah yang sedang dihadapi.

\section{A. Analisa Permasalahan}

Untuk pelaku bisnis yang terbiasa menyimpan data kartu nama pada kontak telepon genggamnya juga terdapat masalah yakni dibutuhkan waktu yang lama untuk menginputkan seluruh informasi dari kartu nama. Selain itu, mereka juga tidak dapat menyimpan gambar dari kartu nama tersebut bersamaan dengan data kontak yang telah disimpan.

Untuk permasalahan yang dimiliki oleh perusahaan, biasanya perusahaan tidak dapat memanajemen seluruh data kartu nama baik itu kartu nama rekan bisnis perusahaan tersebut ataupun kartu nama dari pelanggan-pelanggan perusahaan tersebut. Biasanya data kartu nama itu cukup bergantung kepada karyawan-karyawan tertentu yang berhubungan langsung dengan pemilik kartu nama. Tentunya perusahaan akan sangat mudah kehilangan data kartu nama tersebut ketika karyawan tersebut keluar dan tidak bekerja di perusahaan itu lagi.

Dari analisa yang sudah dilakukan, akan dihasilkan solusi dari masalah yang bersangkutan. Analisa permasalahan adalah analisa dari masalah yang telah disebutkan pada penjelasan sebelumnya. Berikut adalah hasil analisa permasalahan yang dijabarkan dalam bentuk poin-poin:

- Pelaku bisnis sulit untuk menyimpan kartu nama secara fisik, terutama ketika jumlah kartu nama sudah sangat banyak.

- Pelaku bisnis akan membutuhkan waktu yang lama jika harus menginputkan data informasi kartu nama satu per satu.

- Pelaku bisnis tidak dapat menyimpan gambar sekaligus dengan ekstraksi informasi kartu nama pada kontak telepon genggam.

- Perusahaan seringkali kehilangan data kartu nama dari karyawan yang tidak lagi bekerja di perusahaan tersebut

\section{B. Analisa Kebutuhan}

Untuk mulai melakukan analisa, disimpulkan sebuah permasalahan paling dasar dari subbab sebelumnya yaitu mengenai manajemen kartu nama mulai dari menyimpan, menggunakan, hingga pendistribusian kartu nama ke akun perusahaan. Setelah melakukan analisa lebih lanjut, maka terdapat gagasan untuk membuat sistem aplikasi manajemen kartu nama yang memiliki fitur ekstraksi kartu nama otomatis. Dengan fitur ini, pengguna hanya perlu memindai gambar kartu nama lalu memverifikasi hasil dari ekstraksi informasi kartu nama. Dengan demikian, pengguna akan menghemat waktu dalam mengetikkan informasi kartu nama.
Sedangkan untuk permasalahan pada pengguna perusahaan, maka akan dibuat sistem dengan fitur untuk memanajemen karyawan dari perusahaan tersebut. Nantinya, setiap karyawan dapat mengkontribusikan kartu nama yang mereka miliki ke perusahaan sehingga perusahaan dapat memanajemen seluruh data kartu nama dengan baik.

\section{Spesifikasi Kebutuhan Dasar}

Spesifikasi kebutuhan yang dijelaskan akan berupa fiturfitur utama serta teknologi yang sangat diperlukan dalam membuat fitur utama. Fitur utama adalah fitur yang dapat mengurangi atau menyelesaikan permasalahan yang ditemukan sebelumnya. Fitur-fitur utama yang menjadi solusi akan menjadi fitur yang dibuat pada Penelitian ini. Berikut adalah fitur-fitur utama dari sistem ini:

- Ekstraksi Informasi Kartu Nama

Fitur ekstraksi informasi kartu nama merupakan salah satu fitur utama yang akan membantu permasalahan yang ditemukan sebelumnya yakni meningkatkan efisiensi dalam penyimpanan data kartu nama. Dalam fitur ini, pengguna akan menginputkan gambar kartu nama baik melalui galeri atau mengambil gambar secara langsung dengan kamera. Nantinya gambar akan dikirim ke sebuah servis yang dibangun dengan menggunakan framework Flask.

- Manajemen Kartu Nama Perusahaan

Fitur manajemen kartu nama perusahaan ini merupakan fitur yang akan membantu perusahaan menyelesaikan masalah dalam mengatur data kartu nama mereka. Fitur ini akan memperbolehkan perusahaan untuk mengatur karyawan-karyawan mereka ke dalam akun perusahaan mereka. Setiap karyawan bisa berkontribusi untuk menyimpan data kartu nama mereka ke akun perusahaan mereka. Nantinya akun perusahaan dapat mengelola data kartu nama tersebut dan juga membagikan kartu nama itu ke karyawan mereka yang lain, sehingga ketika ada karyawan yang keluar dari perusahaan, maka perusahaan dapat dengan mudah memindahkan atau membagikan kartu nama tersebut ke karyawan yang lain.

\section{Fitur Pelengkap}

Pada bagian ini akan dijelaskan mengenai penjelasan fiturfitur yang akan membangun sistem secara lebih detail. Fiturfitur yang dijelaskan akan menjadi fitur yang dibuat pada sistem ini sebagai pelengkap fitur utama yang telah disebutkan sebelumnya.

- Pencarian dan Pengurutan Kartu Nama

Fitur ini akan membantu pengguna dalam melakukan pencarian kartu nama. Tidak sedikit pengguna yang memiliki data kontak atau kartu nama hingga ratusan bahkan ribuan kartu nama. Dengan fitur ini pengguna dapat memfilter data kartu nama yang akan ditampilkan.

- Membagikan Kartu Nama

Fitur ini dapat digunakan oleh pengguna untuk membagikan kartu nama mereka kepada orang lain melalui sosial media seperti line atau whatsapp. Penerima kartu nama dapat menyimpan kartu nama yang telah dibagikan tersebut. Sedangkan untuk pengguna perusahaan, mereka dapat membagikan kartu nama antar karyawan yang mereka miliki secara massal.

- Melakukan Panggilan dan Mengirim Pesan

Salah satu tujuan dalam menyimpan kartu nama adalah 
untuk menghubungi pemilik kartu nama tersebut, baik melakukan panggilan telepon atau mengirim pesan kepada pemilik kartu nama. Oleh karena itu, fitur ini akan membantu pengguna untuk melakukan panggilan dan juga membuka halaman pembuatan pesan yang langsung memasukkan nomor tujuan pesan secara otomatis.

- Manajemen Berlangganan

Dalam penggunaan sistem ini, akun perusahaan akan dikenakan biaya berlangganan yang akan ditagihkan setiap bulannya. Oleh karena itu, perusahaan akan diminta untuk memasukkan data kartu kredit / kartu debit yang akan digunakan untuk melakukan pembayaran biaya langganan.

- Manajemen Karyawan

Dalam memanajemen kartu nama, perusahaan membutuhkan karyawan-karyawan untuk berkontribusi dalam menambahkan data kartu nama. Oleh karena itu, fitur ini akan digunakan perusahaan untuk menambahkan dan menghapus karyawan. Dalam proses penambahan karyawan, admin perusahaan harus mendaftarkan nomor telepon dari karyawan dan harus menunggu konfirmasi dari karyawan tersebut. Hal ini juga bisa dilakukan dengan cara sebaliknya, pengguna individu mendaftarkan akunnya ke perusahaannya dan admin perusahaan akan mengkonfirmasinya.

- Manajemen Pengguna

Untuk menanggulangi beberapa masalah seperti gagal melakukan pengiriman kode verifikasi atau penyalahgunaan aplikasi, maka super admin dapat memanajemen pengguna dari sistem manajemen kartu nama ini. Super admin dapat melakukan penerimaan verifikasi secara manual pada fitur ini. Selain itu, admin juga dapat memblokir pengguna baik pengguna individu maupun pengguna perusahaan yang dianggap melakukan penyalahgunaan pada sistem manajemen kartu nama ini.

\section{E. Analisa Software Sejenis}

Pada bagian ini akan dijelaskan contoh software sejenis yang sudah ada sebelumnya. Bagian ini juga akan menjelaskan perbandingan terhadap fitur-fitur yang ada pada software sejenis dengan sistem pada Penelitian ini. Ada dua software yang akan menjadi perbandingan, yang pertama adalah Tesis "Pengenalan Layout dan Ekstraksi Teks pada Citra Kartu Nama" oleh Maulidiansyah NRP 213210397 dan yang kedua adalah aplikasi Camcard.

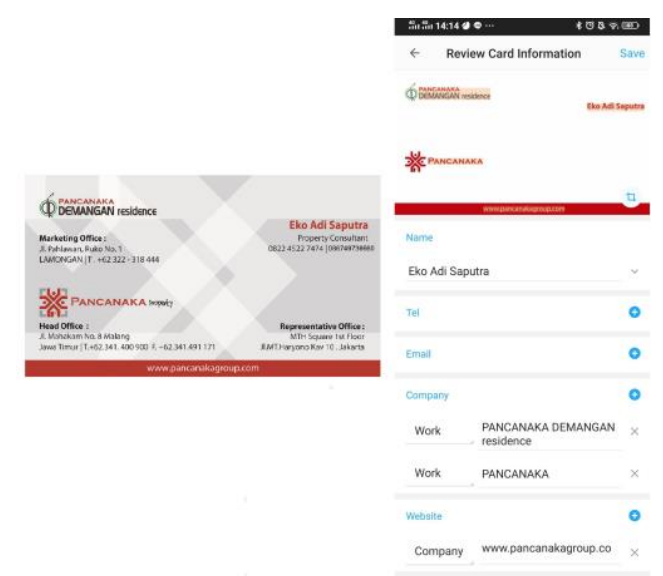

Gambar 1. Contoh Ekstraksi Kartu Nama CamCard
Perbedaan mendasar Penelitian ini dengan tesis "Pengenalan Layout dan Ekstraksi Teks pada Citra Kartu Nama" adalah mengenai aplikasi sistem manajemen kartu nama. Sehingga Penelitian ini, tidak hanya mengekstrak informasi kartu nama tersebut, melainkan juga dapat memanfaatkan hasil dari ekstraksi kartu nama tersebut.

Sedangkan aplikasi kedua, aplikasi Camcard, tidak jauh berbeda dengan sistem manajemen kartu nama pada Penelitian ini. Namun, dengan adanya Penelitian ini diharapkan ekstraksi kartu nama dapat lebih baik dibanding dengan aplikasi Camcard seperti pada Gambar 1. Desain

Pada bagian ini akan dijelaskan tentang desain sistem dari program yang dibuat pada sistem ini. Pada bagian ini, akan dijelaskan desain-desain yang dijelaskan berupa desain arsitektur dan desain tampilan. Desain arsitektur dibutuhkan untuk mengetahui garis besar komponen-komponen yang akan menyusun sistem secara kesuluruhan. Desain tampilan adalah bentuk atau tampilan dari program yang dibuat pada sistem ini.

\section{F. Arsitektur Sistem}

Pada bagian ini akan dijelaskan mengenai arsitektur dari sistem manajemen kartu nama ini. Pengguna sistem ini nantinya harus mengunduh dan menginstall aplikasi ini pada perangkat android untuk dapat menggunakan aplikasi ini. Proses kerja dari aplikasi ini dapat dilihat pada Gambar 2.

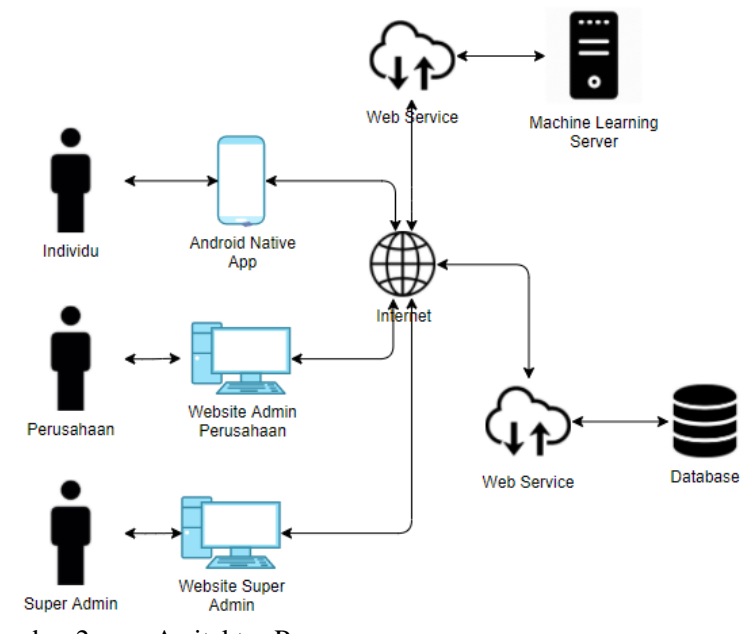

Gambar 2. Arsitektur Program

Dapat dilihat pada Gambar 2 bahwa dalam sistem ini, akan terdapat tiga macam aktor pengguna yakni pengguna individu, perusahaan, dan juga admin sistem ini. Pengguna individu dapat mengakses sistem ini melalui aplikasi mobile berbasis android. Sedangkan untuk pengguna perusahaan dan super admin nantinya akan mengakses sistem ini melalui website.

Dari Gambar 2 juga dapat dilihat bahwa akan ada beberapa program yang akan dibuat pada Penelitian ini agar sistem dapat berjalan dengan baik. Program tersebut adalah android mobile app, website perusahaan, website admin, web service, dan juga machine learning web service. Berikut adalah penjelasan dari masing-masing program tersebut.

- Android Mobile App

Android mobile app pada Penelitian ini akan dibuat secara native menggunakan android studio. Android mobile app ini akan digunakan oleh pengguna individu 
mulai dari proses scan, penyimpanan kartu nama, pencarian, dan sebagainya.

- Website Perusahaan

Website perusahaan akan dibuat menggunakan framework Laravel. Website ini akan digunakan oleh perusahaan yang telah melakukan subscription dalam memanejemen data perusahaan tersebut. Perusahaan akan dapat menyimpan dan memanipulasi data kartu nama mereka melalui website ini.

- Website Admin

Website admin juga akan dibuat menggunakan framework Laravel. Website ini akan digunakan oleh admin dalam mengatur seluruh user dan juga mengatur subscription dari perusahaan yang mendaftar. Penggunaan website admin ini akan dikenakan biaya untuk setiap bulannya yang akan ditagih otomatis melalui kartu kredit / debit.

- Web Service

Web service pada sistem ini akan dibuat menggunakan Lumen. Web service ini akan digunakan untuk melayani seluruh request dari sistem untuk menyimpan dan mengambil data yang dibutuhkan.

- Entity Recognition Web Service

Entity recognition server pada sistem ini akan dibuat menggunakan framework flask. Entity recognition web service ini digunakan untuk melayani request dalam mengekstraksi informasi kartu nama dari gambar yang dikirimkan. Dua proses utama yang dijalankan pada service ini adalah Optical Character Recognition yang dijalankan menggunakan Tesseract dan Named Entity Recognition.

\section{G. Desain Interface}

Pada bagian ini akan diberikan bentuk tampilan dari desain interface pada website dan aplikasi mobile serta penjelasan untuk masing-masing desain interface tersebut. Penjelasan desain interface akan dibagi berdasarkan fitur-fitur yang dibuat. Penjelasan desain interface fitur akan diurutkan berdasarkan kronologis penggunaan fitur secara berurutan, dan diikuti dengan fitur-fitur tambahan.

- Interface Login Register

Pada bagian ini akan dijelaskan desain interface yang diterapkan pada fitur login dan register pada aplikasi mobile sistem manajemen kartu nama. Interface ini akan diberikan kepada pengguna ketika pengguna ingin melakukan login atau registrasi pada aplikasi.

Gambar 3. Tampilan Login

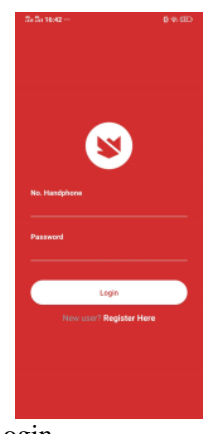

Seperti pada gambar 3 akan terdapat dua input teks, yang pertama adalah unuk nomor telepon pengguna dan kedua adalah untuk password pengguna. Bagian password menggunakan tipe input yang khusus untuk password agar tidak dapat dilihat orang lain saat pengguna mengisinya. Terdapat sebuah tombol yang dapat digunakan untuk login setelah pengguna mengisi kedua input teks. Lalu dibawahnya terdapat sebuah tombol yang dapat digunakan untuk menuju ke halaman registrasi. Berikut adalah gambar desain interface saat pengguna membuka halaman registrasi.

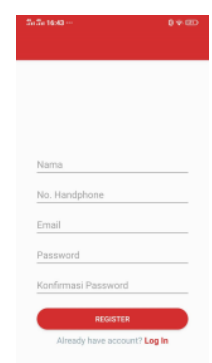

Gambar 4. Tampilan Register

Pada gambar 4 ditampilkan bentuk dari form registrasi pengguna baru. Pada form registrasi terdapat 5 input yang harus diisi agar dapat melakukan registrasi. Input tersebut terdiri dari nama, nomor telepon, email, password, dan konfirmasi password. Pada bagian nomor telepon, pengguna wajib memasukkan nomor teleponnya dengan benar karena pengguna akan menerima kode verifikasi melalui sms yang dikirimkan ke nomor telepon tersebut.

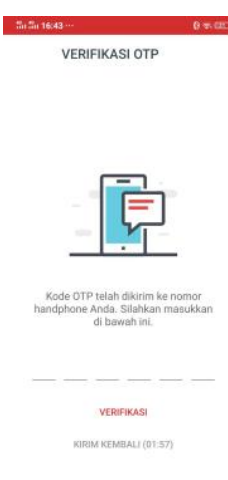

Gambar 5. Tampilan Verifikasi OTP

Setiap pengguna yang baru mendaftarkan diri ke sistem ini, akan menerima kode verifikasi pada nomor teleponnya. Gambar 5 adalah tampilan yang digunakan oleh pengguna untuk memasukkan kode verifikasi yang mereka terima sebelumnya. Ketika pengguna gagal menerima kode verifikasinya, pengguna dapat menekan tombol kirim kembali dengan menunggu selama 2 menit. Setelah pengguna memasukkan kode verifikasi dan menekan tombol verifikasi, maka status pengguna akan menjadi aktif dan akan langsung diarahkan ke halaman daftar kontak.

- Interface Daftar Kontak

Halaman daftar kontak adalah halaman yang digunakan untuk menampilkan seluruh kontak atau kartu nama yang dimiliki pengguna yang sedang login. Pada setiap daftar kontak yang dimiliki, akan muncul tombol dengan logo telepon dan pesan di sebelah kanan nama kontak. Dengan menekan tombol telepon, pengguna akan otomatis dilempar ke halaman dial call dengan nomor tujuan sesuai 
dengan kontak yang dipilih. Begitu pula dengan tombol dengan logo pesan, jika ditekan pengguna akan diarahkan ke halaman pembuatan pesan dengan nomor tujuan sesuai dengan kontak yang dipilih. Gambar halaman daftar kontak ini dapat dilihat pada Gambar 6.

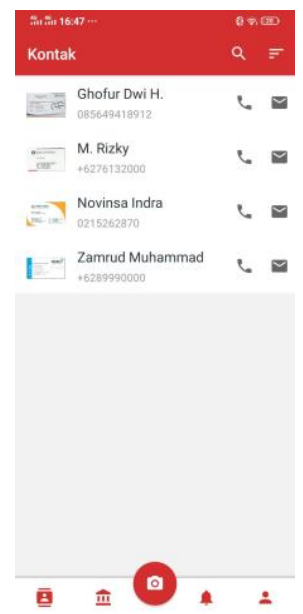

Gambar 6. Tampilan Daftar Kontak

Pada Gambar 6 juga dapat dilihat akan terdapat 5 tombol navigasi di bagian bawah layar. Tombol navigasi ini secara urut adalah tombol navigasi halaman daftar kontak, tombol navigasi halaman daftar perusahaan, tombol navigasi menambah kontak, tombol navigasi halaman notifikasi, dan yang terakhir adalah tombol navigasi halaman profil. Kelima tombol navigasi tersebut akan selalu tampil di halaman-halaman utama pada setiap menunya, sehingga akan memudahkan pengguna untuk berpindah halaman dari halaman yang satu ke halaman yang lainnya.

- Interface Pencarian Kontak

Untuk mempermudah pengguna menampilkan data kontak yang mereka inginkan maka terdapat halaman untuk menginputkan filter sesuai dengan atribut yang diinginkan. Selain itu, pengguna juga dapat mengurutkan tampilan daftar kontak berdasarkan abjad nama atau waktu dari kartu nama tersebut disimpan. Gambar dari tampilan pencarian kontak dapat dilihat pada Gambar 7.

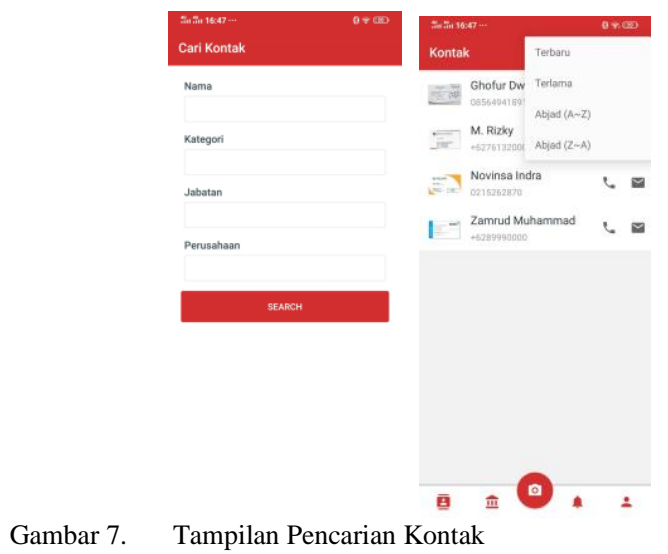

Pada Gambar 7 bagian kiri dapat dilihat bahwa terdapat 4 macam atribut yang dapat digunakan pengguna untuk mencari kartu nama yang diinginkan. Atribut itu adalah nama, kategori, jabatan, dan juga nama perusahaan. Ketika pengguna telah memasukkan data atribut yang akan dicari dan menekan tombol search, maka pengguna akan kembali dilempar ke halaman daftar kontak dengan kontak yang sesuai dengan hasil pencarian. Di halaman daftar kontak bagian kanan atas, terdapat tombol urutkan yang memiliki pilihan untuk merubah urutan tampilan berdasarkan abjad nama atau waktu kartu nama disimpan.

- Interface Daftar Perusahaan

Halaman daftar perusahaan adalah halaman yang digunakan pengguna untuk mengatur perusahaan tempat mereka bergabung. Seperti yang dapat dilihat pada Gambar 8, pengguna dapat memasukkan email perusahaan dan menekan tombol request untuk bergabung ke sebuah perusahaan. Setelah melakukan request, maka daftar perusahaan akan bertambah di bagian bawah tampilan. Pada daftar perusahaan akan muncul nama perusahaan, email perusahaan, dan status dari pengguna. Ketika pertama kali pengguna mendaftarkan dirinya, maka status akan menjadi pending hingga perusahaan menerima permintaan bergabung pengguna.

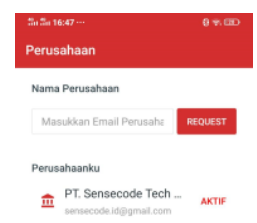

Gambar 8. Tampilan Daftar Perusahaan

- Interface Tambah Kontak

Halaman ini digunakan pengguna untuk menambahkan kontak atau kartu nama baru. Ketika pengguna menekan tombol navigasi tambah kontak, pengguna akan diberikan pilihan antara membuka galeri atau kamera. Tampilan pilihan tersebut dapat dilihat pada Gambar 9 bagian kiri. Setelah pengguna memilih, maka pengguna akan dilempar ke halaman sesuai pilihan pengguna. Pengguna dapat memasukkan gambar kartu nama baik dari galeri atau kamera. Setelah gambar dipilih dan dikirim ke servis, pengguna akan melihat tampilan seperti pada Gambar 9 bagian kanan. Gambar kartu nama dapat diperbesar dan digeser sesuai keinginan pengguna. Atribut dari kartu nama akan otomatis terisi seperti pada gambar, namun ketika pengguna merasa pengisian data tidak sesuai, pengguna dapat menggantinya sesuai dengan opsi pada combobox ataupun mengetiknya secara manual.

- Interface Pengaturan Profil

Halaman pengaturan profil ini akan memiliki beberapa menu yakni untuk mengubah data pengguna, mengubah password, mengubah pengaturan notifikasi, dan informasi mengenai versi aplikasi yang terinstal. Gambar halaman profil ini dapat dilihat pada Gambar 10.

Seperti pada Gambar 10 pada bagian atas akan muncul informasi singkat mulai dari nama, jabatan, dan juga nama perusahaan dari pengguna yang sedang login. Di bawah tampilan tersebut, akan terdapat beberapa menu seperti yang sudah disebutkan sebelumnya. Pada bagian paling 
bawah terdapat tombol keluar yang dapat digunakan pengguna untuk keluar dari aplikasi.

Ketika pengguna menekan tombol menu personal details, maka pengguna akan menuju halaman untuk mengubah profil. Seperti pada Gambar 11 pengguna dapat mengubah profil sesuai input yang ada. Input tersebut terdiri dari nama, nomor telepon, email, alamat, nama perusahaan, dan jabatan. Setelah memasukkan data, pengguna dapat menekan tombol simpan dengan logo centang di pojok kanan atas.

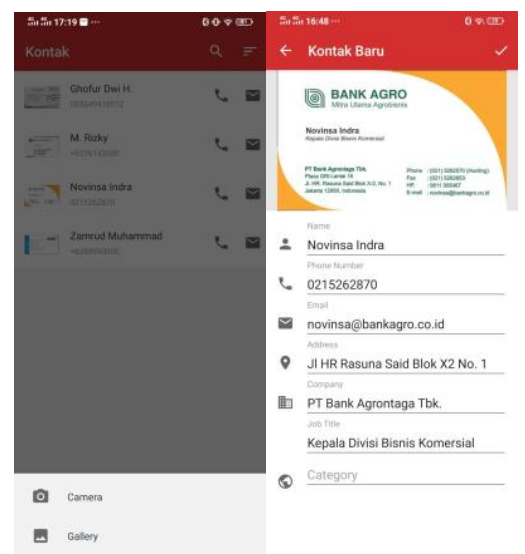

Gambar 9. Tampilan Tambah Kontak

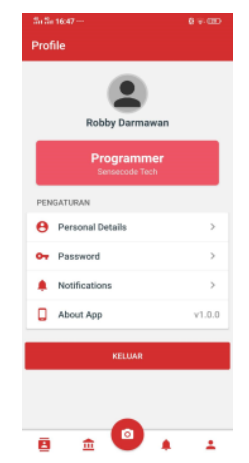

Gambar 10 Tampilan Pengaturan Profil

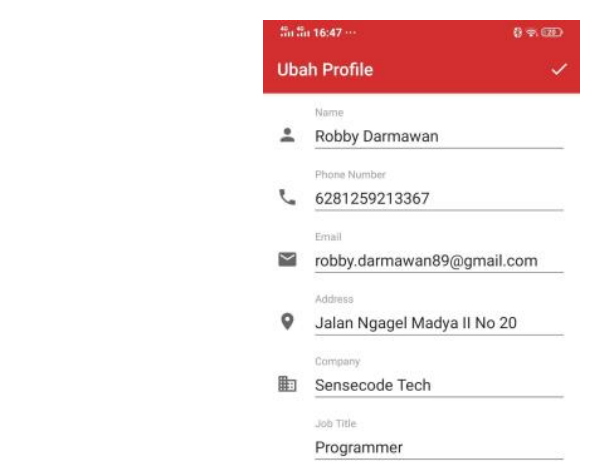

Gambar 11. Tampilan Mengubah Profil

Selain mengubah data profil, pengguna juga dapat mengubah password dengan menekan tombol menu password di halaman pengaturan profil. Saat akan mengubah password, pengguna haru menginputkan data password lama, password baru, dan konfirmasi password baru. Setelah memasukkan data password, pengguna dapat menyimpan passwordnya dengan menekan tombol simpan di bagian bawah form ubah password.

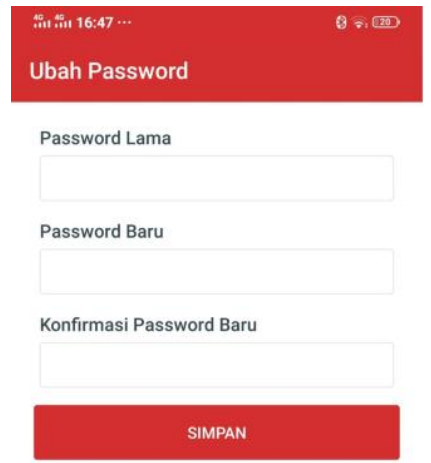

Gambar 12 Tampilan Mengubah Password

- Interface Login Register Admin

Halaman login register admin akan digunakan oleh pengguna perusahaan untuk masuk ke sistem ini melalui website. Untuk dapat masuk ke sistem, pengguna harus memasukkan email dan juga password dari akun perusahaan yang sudah didaftarkan sebelumnya. Tampilan login dari website dapat dilihat pada Gambar 13.

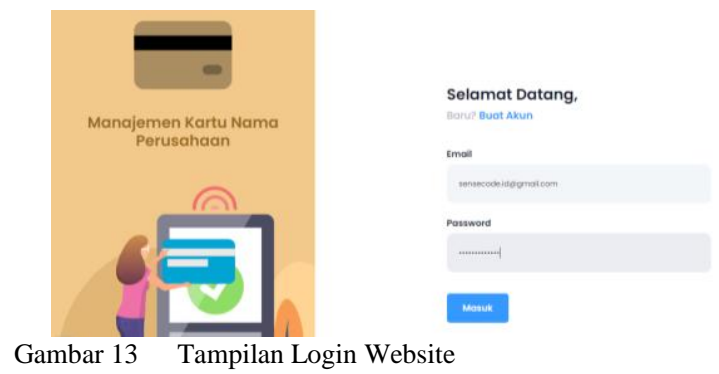

Seperti pada Gambar 13, untuk pengguna baru yang ingin mendaftarkan perusahaannya, pengguna dapat menekan tombol buat akun yang berada di bagian tengah atas tampilan. Sedangkan untuk masuk, pengguna hanya perlu memasukkan email dan password lalu menekan tombol masuk yang ada pada halaman login.

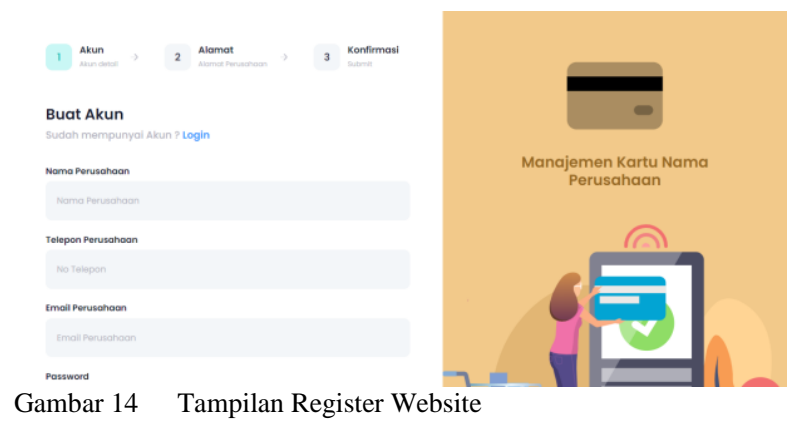

Ketika pengguna menekan tombol buat akun, maka pengguna akan dialihkan ke halaman register seperti pada Gambar 14. Form pengisian data perusahaan akan berupa wizard. Di wizard yang pertama, pengguna diminta untuk memasukkan data akun perusahaan mulai dari nama perusahaan, telepon perusahaan, email perusahaan, dan password untuk masuk ke sistem ini. 


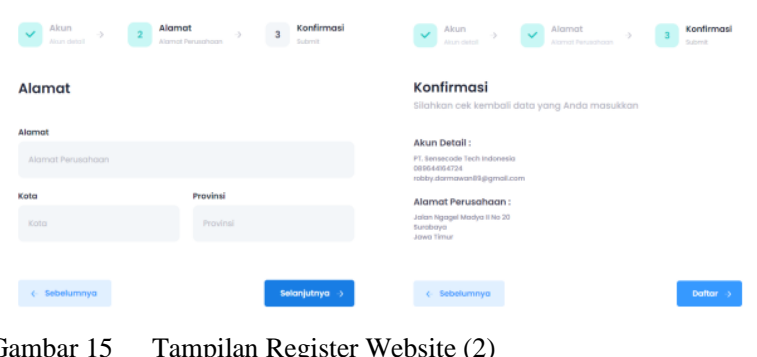

Gambar 15 Tampilan Register Website (2)

Pada wizard kedua yang dapat dilihat pada Gambar 15, pengguna diminta untuk memasukkan data alamat dari perusahaan yang akan didaftarkan. Setelah itu, pengguna akan dialihkan ke wizard ketiga untuk mengkonfirmasi data yang dimasukkan telah benar. Setelah perusahaan berhasil mendaftarkan perusahaannya, perusahaan akan menerima email verifikasi sesuai dengan email yang telah dimasukkan sebelumnya. Setelah pengguna melakukan email verifikasi, pengguna akan langsung diarahkan ke halaman website perusahaan.

- Interface Pengaturan Langganan

Pengguna perusahaan, dapat melakukan pembayaran biaya langganan menggunakan kartu kredit atau kartu debit yang memiliki visa atau mastercard. Di halaman pengaturan langganan ini, pengguna dapat memasukkan informasi kartu mereka mulai dari nomor kartu, tanggal kadaluarsa kartu, dan juga cvv kartu. Selain itu, di bagian sebelah kiri seperti pada Gambar 16, pengguna juga dapat melihat informasi biaya dan tanggal penagihan selanjutnya.

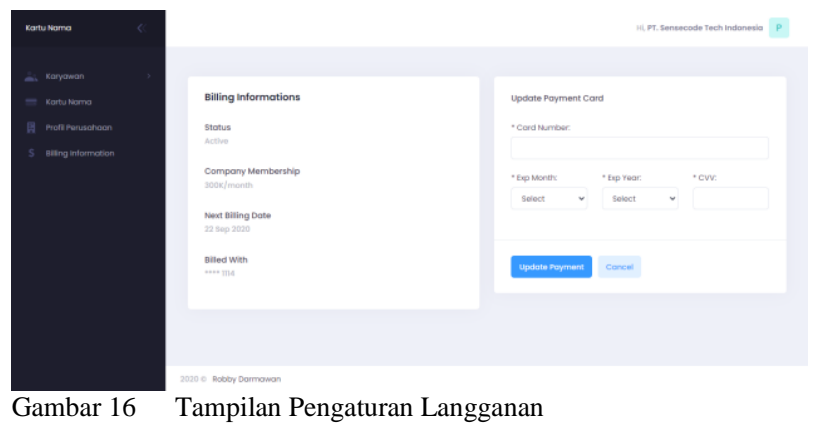

- Interface Pengaturan Profil Perusahaan

Perusahaan dapat mengatur profilnya di menu profil perusahaan. Ada dua submenu yang dapat dipilih oleh pengguna yakni, submenu informasi perusahaan dan submenu ubah kata sandi. Seperti pada Gambar 17, pengguna dapat mengubah informasi perusahaan pada input teks dan menekan tombol simpan pada bagian kanan atas. Sedangkan untuk mengubah kata sandi, pengguna harus memasukkan kata sandi lama terlebih dahulu untuk dapat mengubahnya menjadi kata sandi yang baru.

- Interface Karyawan Perusahaan

Tampilan karyawan perusahaan, merupakan tampilan yang digunakan akun perusahaan untuk mengatur data karyawan yang bergabung ke akun perusahaannya tersebut. Seperti pada Gambar 18, perusahaan dapat menambahkan karyawan dengan memasukkan nomor telepon karyawan dan menekan tombol tambah pada bagian kanan atas. Setelah ditambahkan, status karyawan akan pending hingga karyawan tersebut menerima undangan bergabung dari perusahaan tersebut.
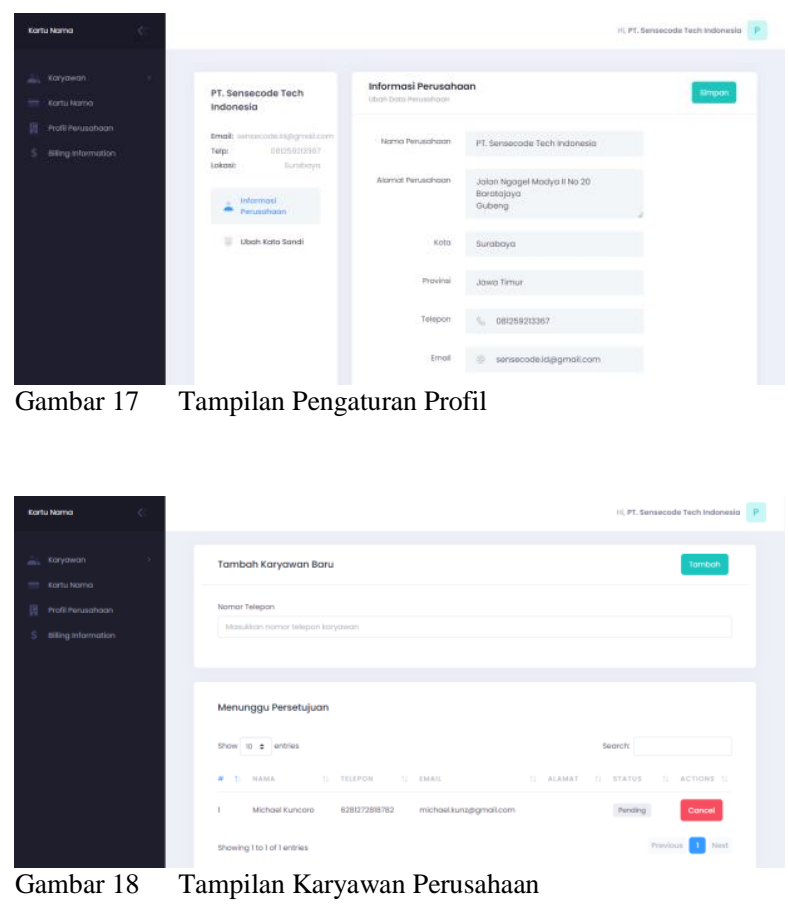

- Interface Kartu Nama Perusahaan

Setiap karyawan yang sudah bergabung dengan perusahaan dapat berkontribusi untuk menambahkan data kartu nama perusahaan yang baru. Daftar kartu nama tersebut akan muncul pada halaman kartu nama seperti pada Gambar 19. Pada tampilan tersebut dapat dilihat bahwa ada dua menu untuk masing-masing kartu nama. Menu yang pertama adalah menu gambar yang akan menampilkan gambar dari kartu nama yang disimpan oleh karyawan. Sedangkan menu kedua adalah menu data yang akan menampilkan seluruh informasi dari kartu nama tersebut. Untuk memudahkan pengguna dalam memanfaatkan informasi tersebut, pengguna dapat melakukan beberapa aksi pada menu data. Beberapa aksi tersebut adalah melakukan panggilan telepon, mengirim email, dan yang terakhir adalah membuka peta sesuai dengan alamat yang tertera pada kartu nama.
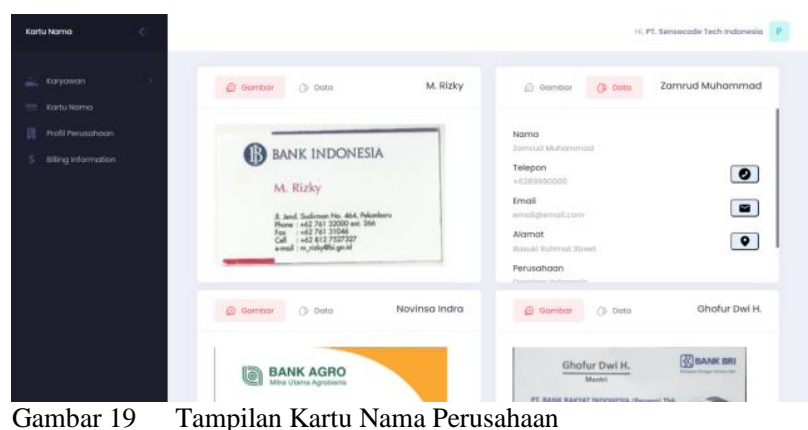

Gambar 19 Tampilan Kartu Nama Perusahaan

- Interface Manajemen Pengguna

Tampilan manajemen pengguna ini akan digunakan oleh super admin untuk mengatur akun pengguna. Super admin dapat melihat daftar pengguna individu maupun perusahaan pada menu yang ada. Dapat dilihat pada Gambar 20, super admin dapat melakukan beberapa aksi seperti memblokir pengguna, menerima aktivasi secara 
manual, dan mengaktifkan ulang pengguna yang telah diblokir sebelumnya.

\section{- Interface Riwayat Pembayaran}

Seperti yang dijelaskan sebelumnya, pengguna perusahaan akan dikenakan biaya langganan setiap bulannya. Oleh karena itu, super admin dapat melihat riwayat dari pembayaran biaya langganan pada menu riwayat pembayaran. Tampilan riwayat pembayaran dapat dilihat pada Gambar 21.

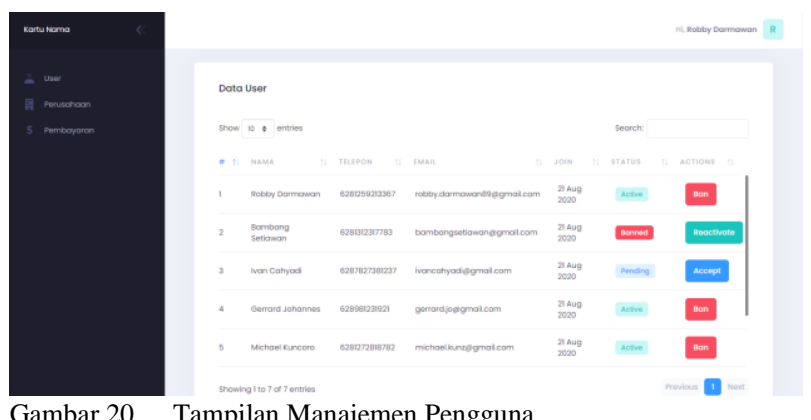

Gambar 20 Tampilan Manajemen Pengguna

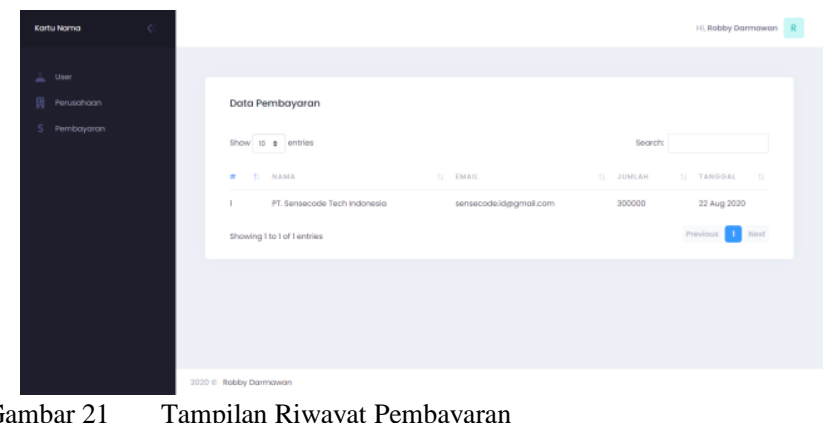

\section{EKSTRAKSI INFORMASI KARTU NAMA}

Pada bagian ini akan dijelaskan tentang proses ekstraksi dari pengenalan informasi pada kartu nama yang dibuat untuk penelitian ini. Proses ekstraksi informasi pada kartu nama ini akan dibahas akan dibagi menjadi 5 bagian yaitu implementasi untuk pengenalan kartu, preprocessing gambar, pengenalan karakter, penentuan entity kartu nama dan implementasinya pada webservice flask. Gambar 22 adalah arsitektur dari ektraksi informasi kartu nama pada Penelitian ini.

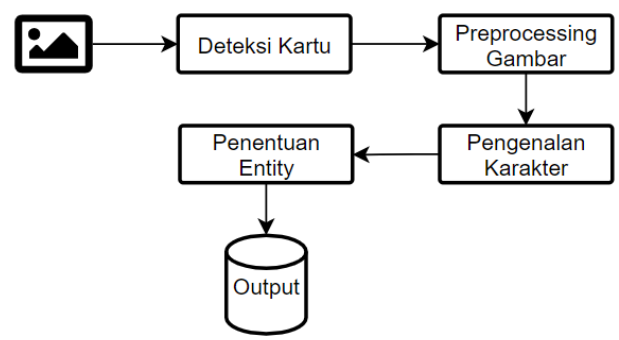

Gambar 22 Arsitektur Ekstraksi Kartu Nama

Dalam proses ekstraksi ini, sistem akan memiliki input berupa gambar dan mengeluarkan output berupa array of object. Array of object ini adalah objek dengan pasangan data beserta tipe entity hasil dari ekstraksi kartu nama. Gambar yang menjadi input pada sistem ini akan melewati 4 proses utama yakni, pendeteksian kartu, preprocessing gambar, pengenalan karakter, dan penentuan entity. Masing-masing proses akan dijelaskan satu per satu secara detail dengan potongan program dan gambar hasil dari masing-masing proses.

\section{A. Pengenalan Kartu}

Saat pertama kali webservice menerima gambar dari program, webservice akan memotong terlebih dahulu bagian background dari gambar yang bukan merupakan bagian dari kartu nama. Hal ini dilakukan dengan mendeteksi bentuk kotak pada gambar. Pendeteksian tepi dari objek gambar dilakukan dengan menggunakan metode canny. Input dan output dari hasil pendeteksian tepi ini dapat dilihat pada Gambar 23.
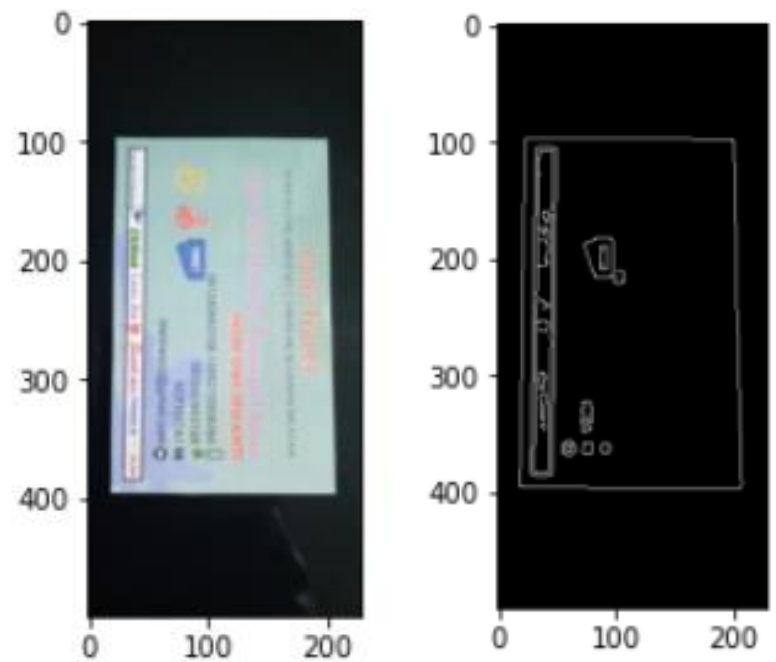

Gambar 23 Input Ouput Deteksi Tepi dengan Canny

\section{B. Preprocessing Gambar}

Setelah mendapatkan potongan kartu nama, program akan melakukan preprocessing sebelum ocr dilakukan. Hal ini tentunya bertujuan untuk memperoleh hasil ocr yang lebih baik. Preprocessing yang dilakukan dimulai dari perbaikan orientasi gambar dan membuang noise pada gambar.

Pertama, program akan mendapatkan nilai orientasi gambar dengan memanfaatkan fungsi pada pytesseract yakni image_to_osd. Fungsi ini akan mengembalikan string data dari orientasi gambar. Oleh karena itu, selanjutnya digunakan regex untuk mendapatkan nilai orientasi dari string yang telah didapatkan sebelumnya. Selanjutnya, program akan menggunakan fungsi rotate dari ndimage untuk memutar gambar sehingga gambar akan memiliki orientasi yang tepat. Setelah memiliki orientasi yang tepat, program akan melakukan beberapa perbaikan pada gambar, semisalnya menghilangkan beberapa noise dengan melakukan thresholding. Hasil dari preprocessing gambar ini dapat dilihat pada Gambar 24.

Dalam preprocessing gambar ini, dilakukan beberapa proses untuk mengolah gambar sehingga gambar yang akan dijalankan pada proses pengenalan karakter dengan tesseract OCR menjadi lebih maksimal. Beberapa faktor seperti terang gelapnya warna background dan juga background yang bertekstur akan dihilangkan pada tahap preprocessing gambar ini. 

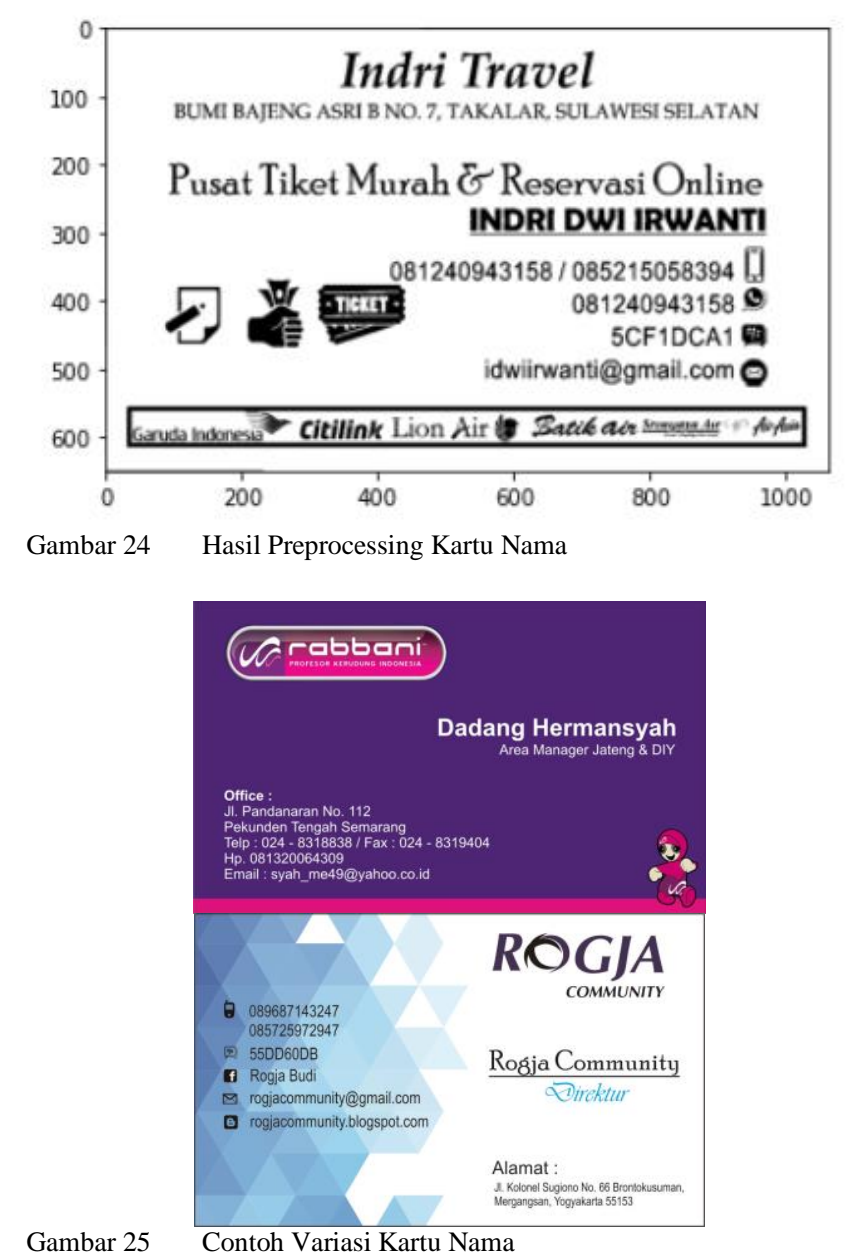

Gambar 25 adalah contoh variasi dari gambar kartu nama. Dari gambar tersebut, dapat dilihat bahwa desain dari kartu nama sangat beragam baik dari pewarnaan dan juga tipe font. Gambar 25 bagian kiri merupakan contoh kartu nama yang memiliki warna background gelap dan bagian kanan merupakan contoh kartu nama yang memiliki warna background terang namun memiliki tekstur background yang bisa saja mengganggu proses pengenalan karakter yang dilakukan oleh tesseract OCR.

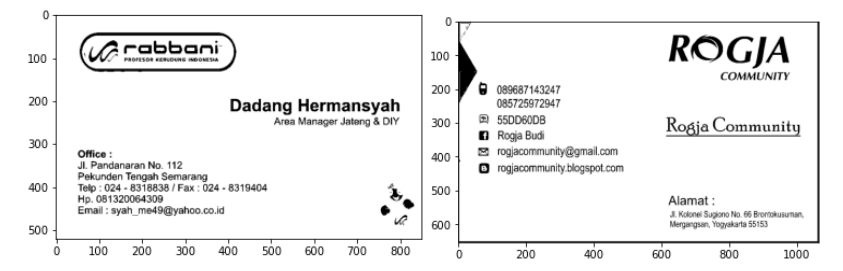

Gambar 26 Hasil Preprocessing Kartu Nama

Gambar 26 adalah hasil dari preprocessing Gambar 25. Tahap ini akan melakukan thresholding terhadap background yang ada sehingga warna background yang mengganggu proses pengenalan karakter dapat dihilangkan. Selain itu, untuk gambar yang memiliki warna background yang gelap, akan dibalik nilainya sehingga warna background akan menjadi warna yang terang (putih).

\section{Pengenalan Karakter}

Setelah gambar kartu nama selesai melalui proses preprocessing, maka gambar akan dilanjutkan ke proses ocr memanfaatkan tesseract [9]. Proses ocr pada Penelitian ini akan memanfaatkan library pytesseract dan mengikuti pendekatan pada [10] dan [11]. Sebelum melalui proses ocr, gambar yang sudah mengalami preprocessing akan dibagibagi sesuai kontur yang ada seperti pada Gambar 27. Hal ini bertujuan untuk memisahkan tulisan jika ada gambar yang memiliki desain informasi beberapa kolom.

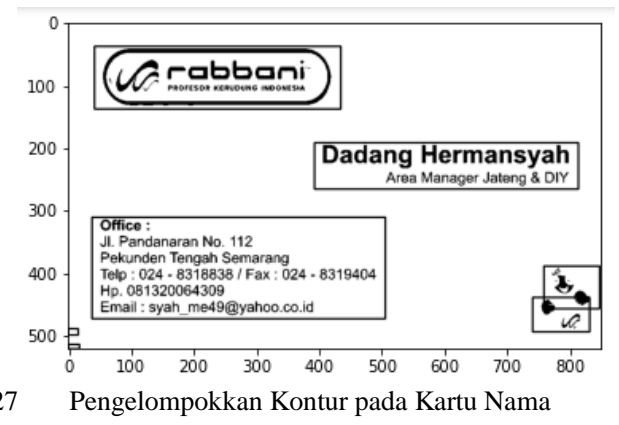

Gambar 27 merupakan contoh hasil dari pengelompokkan kontur pada gambar kartu nama. Hal ini dilakukan untuk dapat memisahkan kata ketika terdapat informasi atau tulisan yang terdiri dari beberapa kolom pada satu baris. Dari masing-masing kontur tersebut, akan dipotong dan dilakukan pengenalan karakter satu persatu.

\section{Penentuan Entity Kartu Nama}

Array variabel hasil proses ocr sebelumnya akan diklasifikasikan satu per satu manfaatkan teknik information extraction pada [12]. Pengklasifikasian entity akan memiliki dua macam klasifikasi. Klasifikasi yang pertama berdasarkan aturan yang dibuat dan yang kedua menggunakan model yang telah dibuat. Untuk klasifikasi yang pertama, hanya akan menghasilkan klasifikasi entity dengan tipe nomor telepon, email, dan website. Klasifikasi ini akan menggunakan regular expression untuk dapat mengklasifikasikan entity yang diinginkan.

\section{E. Implementasi Webservice Flask}

Pada bagian ini akan dijelaskan mengenai pengimplementasian program-program yang sudah dijelaskan sebelumnya ke dalam webservice. Untuk mengimplementasikan seluruh program yang telah dijelaskan sebelumnya, sistem membutuhkan sebuah framework yang dapat menjalankan bahasa pemrograman python dan juga menjadi sebuah service yang dapat dipanggil oleh aplikasi mobile.

Sistem manajemen kartu nama pada Penelitian ini akan memanfaatkan framework Flask sebagai webservice ekstraksi informasi pada gambar kartu nama. Karena framework ini menggunakan bahasa python maka sebelum menggunakan framework ini tentunya terlebih dahulu harus menginstal python dan pip pada perangkat yang akan digunakan.

Setelah program Flask berhasil dibuat, tentunya perlu ada beberapa baris program yang dibuat supaya webservice Flask dapat dipanggil dari aplikasi kita. Setiap potongan program yang telah dibuat sebelumnya, akan dijadikan satu pada file app.py di dalam proyek Flask yang telah dibuat. Masingmasing program akan dimasukkan ke dalam fungsi sehingga mudah dipanggil oleh main program yang akan menjadi webservice pada sistem Penelitian ini.

Data yang dikembalikan akan berupa array yang masingmasing merupakan objek data dan entity dari hasil ekstraksi. 
Selain itu, webservice juga akan mengembalikan data gambar yang telah diproses dan diubah dalam bentuk base 64 .

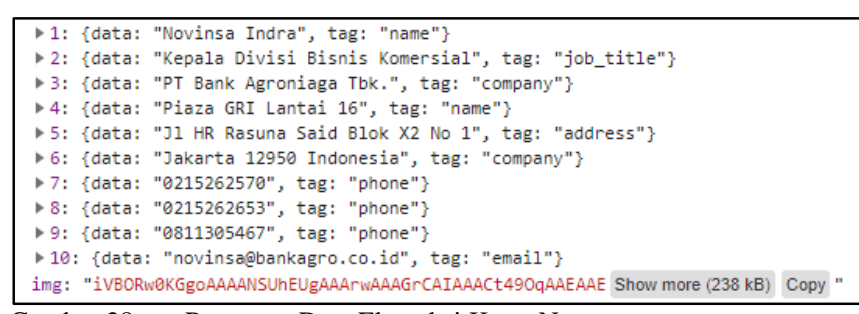

Gambar 28 Response Data Ekstraksi Kartu Nama

\section{UJI COBA}

Pada bagian ini akan dijelaskan mengenai uji coba yang dilakukan pada Penelitian Sistem Manajemen Kartu Nama dengan Ekstraksi Informasi Kartu Nama Otomatis. Uji coba merupakan tahap dalam pembuatan sebuah sistem untuk dapat mengetahui fungsionalitas dan kemampuan yang dimiliki oleh sistem yang dibuat. Uji coba akan mencakup pengujian fungsionalitas dengan metode blackbox testing dan usability dari penggunaan sistem yang telah dibuat. Selain itu juga akan dilakukan uji coba untuk mengetahui akurasi dari ekstraksi informasi kartu nama.

\section{A. Uji Coba Fungsionalitas}

Pada bagian ini akan dijelaskan mengenai uji coba yang dilakukan oleh developer secara langsung. Uji coba akan dilakukan dengan menggunakan blackbox testing. Uji coba ini dilakukan untuk mengetahui apakah fungsionalitas aplikasi berjalan dengan baik dan sesuai dengan yang dirancangkan pada bab sebelumnya. Uji coba ini akan dilakukan untuk masing-masing fitur yang ada pada aplikasi. Dari hasil uji coba ini, sistem yang dibuat telah memberikan output sesuai target yang diharapkan untuk setiap aksi yang dilakukan oleh pengguna.

\section{B. Uji Coba Usability}

Pada bagian ini akan dipaparkan hasil dari uji coba sistem yang dilakukan oleh pengguna secara langsung. Uji coba dilakukan kepada 25 orang yang akan mencoba menggunakan sistem sebagai user individu dengan aplikasi mobile dan 7 orang akan mencoba menggunakan sistem sebagai user perusahaan dengan aplikasi website. Dalam uji coba ini, aplikasi juga mengalami uji coba compatibility dimana aplikasi dijalankan setidaknya pada 7 tipe handphone yang berbeda seperti Vivo S1, Redmi Note 7, Huawei Honor Play, Oppo F7, dsb. Setelah mencoba semua fitur yang ada pada aplikasi, tester diberikan sebuah kuesioner untuk mengetahui response dari sisi pengguna menggunakan Google Form.

Tabel II merupakan hasil kuesioner dari pertanyaan yang telah diajukan kepada tester setelah mencoba seluruh fitur pada aplikasi dengan skala penilaian dari 1 sampai 4. Nilai 1 merupakan nilai yang paling rendah dan 4 merupakan nilai yang paling tinggi. Pertanyaan pada nomor 1 hingga nomor 7 merupakan pertanyaan yang diajukan kepada tester yang telah mencoba menggunakan aplikasi mobile sebagai pengguna individu pada sistem ini. Untuk pertanyaan nomor 8 hingga nomor 14 merupakan pertanyaan yang diajukan kepada tester yang menggunakan website sebagai admin perusahaan pada sistem ini.

\section{Uji Coba Akurasi}

Pada bagian ini akan dijelaskan hasil dari uji coba fitur ekstraksi informasi kartu nama. Uji coba ini akan menghitung akurasi dari proses pengenalan karakter dan juga klasifikasi entity dari kartu nama tersebut. Uji coba ini akan menghasilkan persentase akurasi dari pengujian ekstraksi kartu nama. Berikut ini adalah beberapa contoh dari proses uji coba yang dilakukan.

TABEL II HASIL KUESIONER

\begin{tabular}{|c|c|c|c|c|}
\hline Pertanyaan & $\begin{array}{c}1 \\
\text { Poin }\end{array}$ & $\begin{array}{c}2 \\
\text { Poin }\end{array}$ & $\begin{array}{c}3 \\
\text { Poin }\end{array}$ & $\begin{array}{c}4 \\
\text { Poin }\end{array}$ \\
\hline $\begin{array}{l}\text { Bagaimana tampilan aplikasi dari } \\
\text { Sistem Manajemen Kartu Nama? }\end{array}$ & $0 \%$ & $4 \%$ & $28 \%$ & $68 \%$ \\
\hline $\begin{array}{l}\text { Bagaimana performa aplikasi yang } \\
\text { disajikan? }\end{array}$ & $0 \%$ & $0 \%$ & $60 \%$ & $40 \%$ \\
\hline $\begin{array}{l}\text { Kemudahan dalam menggunakan } \\
\text { aplikasi }\end{array}$ & $0 \%$ & $4 \%$ & $48 \%$ & $48 \%$ \\
\hline $\begin{array}{l}\text { Kemudahan sistem navigasi pada } \\
\text { aplikasi }\end{array}$ & $0 \%$ & $0 \%$ & $44 \%$ & $56 \%$ \\
\hline $\begin{array}{l}\text { Kemudahan dalam menambahkan } \\
\text { kartu nama }\end{array}$ & $0 \%$ & $8 \%$ & $48 \%$ & $44 \%$ \\
\hline $\begin{array}{l}\text { Ketepatan ekstraksi kartu nama } \\
\text { otomatis }\end{array}$ & $0 \%$ & $20 \%$ & $48 \%$ & $32 \%$ \\
\hline $\begin{array}{l}\text { Apakah anda merasa terbantu } \\
\text { untuk mengelola kartu nama } \\
\text { dengan aplikasi ini? }\end{array}$ & $0 \%$ & $4 \%$ & $48 \%$ & $48 \%$ \\
\hline $\begin{array}{l}\text { Bagaimana tampilan website dari } \\
\text { Sistem Manajemen Kartu Nama? }\end{array}$ & $0 \%$ & $0 \%$ & $14.3 \%$ & $85.7 \%$ \\
\hline $\begin{array}{l}\text { Bagaimana performa website yang } \\
\text { disajikan? }\end{array}$ & $0 \%$ & $0 \%$ & $57.1 \%$ & $42.9 \%$ \\
\hline $\begin{array}{l}\text { Kemudahan dalam menggunakan } \\
\text { website }\end{array}$ & $0 \%$ & $0 \%$ & $28.6 \%$ & $71.4 \%$ \\
\hline $\begin{array}{l}\text { Kemudahan sistem navigasi pada } \\
\text { website }\end{array}$ & $0 \%$ & $0 \%$ & $57.1 \%$ & $42.9 \%$ \\
\hline $\begin{array}{l}\text { Kemudahan dalam mengelola } \\
\text { karyawan perusahaan }\end{array}$ & $0 \%$ & $0 \%$ & $42.9 \%$ & $57.1 \%$ \\
\hline $\begin{array}{l}\text { Kemudahan dalam mengelola } \\
\text { langganan }\end{array}$ & $0 \%$ & $0 \%$ & $28.6 \%$ & $71.4 \%$ \\
\hline $\begin{array}{l}\text { Apakah anda merasa terbantu } \\
\text { untuk mengelola kartu nama } \\
\text { karyawan dengan sistem ini? }\end{array}$ & $0 \%$ & $10 \%$ & $50 \%$ & $40 \%$ \\
\hline
\end{tabular}

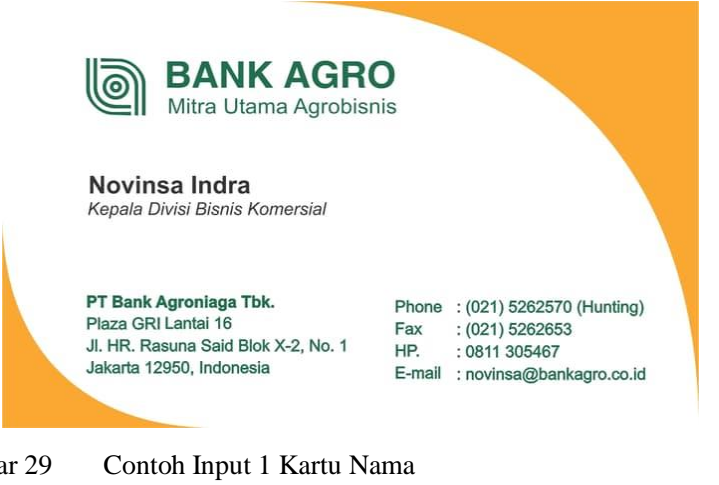

Gambar 29 Contoh Input 1 Kartu Nama

Tabel III merupakan hasil uji coba dari pengenalan karakter dan klasifikasi entity yang dihasilkan oleh sistem dengan menerima input seperti Gambar 29. Contoh input dan output tersebut merupakan salah satu uji coba yang memiliki akurasi yang tinggi baik dalam pengenalan karakter dan juga pengklasifikasian entity. Hampir seluruh data pada kartu nama Gambar 29 dapat diekstrak dengan baik.

Uji coba untuk proses pengenalan karakter ini akan menghitung akurasi dari setiap karakter yang dihasilkan. Pada pengujian ini, tingkat kesalahan pengenalan karakter akan dihitung menggunakan metode levensthein distance. 
Levensthein distance adalah algoritma yang mengukur kesamaan antara 2 string. Dalam pengujian pengenalan karakter ini, pengujian dilakukan menggunakan 30 macam kartu nama yang dapat dilihat pada lampiran A. Dari pengujian ini terdapat 5028 karakter dengan tingkat kesalahan 749. Dengan perhitungan (Total Karakter Kesalahan) / Total Karakter * 100\%, maka dapat disimpulkan bahwa pengenalan karakter dari sistem ini memiliki akurasi sebesar $85.1 \%$. Sedangkan untuk penghitungan akurasi pada klasifikasi entity menggunakan rata-rata dari F1 score yang diperoleh dari nilai precision dan recall untuk masing-masing entity. Dari perhitungan tersebut, akurasi klasifikasi pada sistem kartu nama ini adalah $86 \%$.

TABEL III

OUTPUT 1 KARTU NAMA

\begin{tabular}{llc}
\hline \hline No & \multicolumn{1}{c}{ Output Pengenalan Karakter } & Output Klasifikasi Entity \\
\hline 1 & BANK AGRO & Company \\
2 & Novinsa Indra & Name \\
3 & Kepala Divisi Bisnis Komersial & Job Title \\
4 & PT Bank Agroniaga Tbk. & Company \\
5 & Plaza GRI Lantai 16 & Address \\
6 & Jl. HR. Rasuna Said Blox X-2, & Address \\
& No. 1 & \\
7 & Jakarta 12950, Indonesia & Company \\
8 & 0215262570 & Phone \\
9 & 0215262653 & Phone \\
10 & 0811305467 & Phone \\
11 & novinsa@ bankagro.co.id & Email \\
\hline
\end{tabular}

\section{KESIMPULAN}

Pada bagian ini akan dijelaskan mengenai kesimpulan yang diperoleh setelah pembuatan Sistem Manajemen Kartu Nama dengan Ekstraksi Informasi Kartu Nama Otomatis. Berikut adalah kesimpulan yang telah diperoleh dalam pembuatan sistem ini.

- Ekstraksi Informasi Otomatis dapat mempermudah pengguna dalan menyimpan kartu nama.

- Perusahaan dapat memanajemen kartu nama dengan mudah dan tidak perlu khawatir kehilangan data kartu nama dari karyawan perusahaan.

- Microframework Flask merupakan solusi mudah dalam membuat webservice yang membutuhkan bahasa pemrograman Python beserta library-library Python.

- Klasifikasi data yang menggabungkan klasifikasi berbasis aturan dan klasifikasi menggunakan model Naive Bayes dapat menghasilkan ekstrak informasi kartu nama dengan cukup baik.

- Hasil uji coba pengenalan karakter pada sistem Penelitian ini memiliki akurasi sebesar $85.1 \%$.

- Hasil uji coba pengklasifikasian entity pada sistem Penelitian ini memiliki akurasi sebesar $86 \%$.

\section{DAFTAR PUSTAKA}

[1] Santoso, Sugeng, Josch Kauf, and Nabila Cynthia Aristo. "The Information System of Name Card Sales Based on Digital Marketing to Improve Creativepreneur on College E-Commerce Website." Aptisi Transactions On Technopreneurship (ATT) 1.1 (2019): 64-72.

[2] Vuong, Bao Quoc, and Hung Ngoc Do. "Design and implementation of multilanguage name card reader on Android platform." 2014 International Conference on Advanced Technologies for Communications (ATC 2014). IEEE, 2014.

[3] Yener, M., Dundar, O. 2016. Expert Android Studio. Wrox.
[4] He, Ren Yu. "Design and implementation of web based on Laravel framework." 2014 International Conference on Computer Science and Electronic Technology (ICCSET 2014). Atlantis Press, 2015.

[5] Redmond, Paul. "Lumen Programming Guide." New York: Penerbit Apress Media (2016).

[6] Dwyer, Gareth. 2016. Flask By Example. Packt Publishing.

[7] Smith, Ray. "An overview of the Tesseract OCR engine." Ninth international conference on document analysis and recognition (ICDAR 2007). Vol. 2. IEEE, 2007.

[8] Pedregosa, Fabian, et al. "Scikit-learn: Machine learning in Python." the Journal of machine Learning research 12 (2011): 2825-2830.

[9] Smith, Ray W. "History of the Tesseract OCR engine: what worked and what didn't." Document Recognition and Retrieval XX. Vol. 8658 International Society for Optics and Photonics, 2013

[10] Thakare, Sahil, et al. "Document Segmentation and Language Translation Using Tesseract-OCR." 2018 IEEE 13th International Conference on Industrial and Information Systems (ICIIS). IEEE, 2018.'

[11] Warsito, Amelia Alexandra Putri, and Herry Pieter. "Aplikasi Manajemen Hutang Piutang dengan OCR Berbasis Swift." Journal of Intelligent System and Computation 2.2 (2020): 47-55.

[12] Ferdinandus, F. X., et al. "Optical Character Recognition Dan Information Extraction Pada Dokumen Kamus Bilingual." Inov. dalam Desain dan Teknol (2011): 302-308. 